University of Nebraska - Lincoln

DigitalCommons@University of Nebraska - Lincoln

Sources of terrestrially-derived organic carbon in lower

Mississippi River and Louisiana shelf sediments: implications for differential sedimentation and transport at the coastal margin

\author{
Thomas S. Bianchi \\ Tulane University, tbianch@tulane.edu \\ Siddhartha Mitra \\ USGS, smitra@usgs.gov \\ Brent A. McKee \\ Tulane University, bmckee@unc.edu
}

Follow this and additional works at: https://digitalcommons.unl.edu/usgsstaffpub

Bianchi, Thomas S.; Mitra, Siddhartha; and McKee, Brent A., "Sources of terrestrially-derived organic carbon in lower Mississippi River and Louisiana shelf sediments: implications for differential sedimentation and transport at the coastal margin" (2002). USGS Staff -- Published Research. 535. https://digitalcommons.unl.edu/usgsstaffpub/535

This Article is brought to you for free and open access by the US Geological Survey at DigitalCommons@University of Nebraska - Lincoln. It has been accepted for inclusion in USGS Staff -- Published Research by an authorized administrator of DigitalCommons@University of Nebraska - Lincoln. 


\title{
Sources of terrestrially-derived organic carbon in lower Mississippi River and Louisiana shelf sediments: implications for differential sedimentation and transport at the coastal margin
}

\author{
Thomas S. Bianchi ${ }^{\mathrm{a}, *}$, Siddhartha Mitra ${ }^{\mathrm{a}, \mathrm{b}}$, Brent A. McKee ${ }^{\mathrm{c}}$ \\ ${ }^{a}$ Department of E.E. Biology, Institute for Earth and Ecosystem Sciences, Tulane University, New Orleans, LA 70118, USA \\ ${ }^{\mathrm{b}}$ USGS, 345 Middlefield Road-MS 999, Menlo Park, CA 94025, USA \\ ${ }^{\mathrm{c}}$ Department of Geology, Institute for Earth and Ecosystem Sciences, Tulane University, New Orleans, LA 70118, USA
}

Received 22 May 2001; received in revised form 26 November 2001; accepted 30 November 2001

\begin{abstract}
In this study, we examined the temporal and spatial variability of terrestrial organic carbon sources in lower Mississippi River and Louisiana shelf sediments (during 11 cruises over a 22-month period) to further understand the sorting dynamics and selective transport of vascular plant materials within the primary dispersal system of the river. Bulk $\delta^{13} \mathrm{C}$ values in lower river sediments ranged from $-21.90 \%$ to $-24.64 \%$ o (mean $=-23.20 \pm 1.09 \%$ ), these values were generally more depleted than those found in shelf sediments ( $-22.5 \%$ to $-21.2 \%$ ). The $\Lambda_{8}\left(\Lambda_{8}=\right.$ sum of vanillyl, syringyl and cinnamyl phenols produced from the oxidation of $100 \mathrm{mg}$ of organic carbon) values in the lower river ranged from 0.71 to 3.74 (mean $=1.78 \pm 0.23$ ). While there was no significant relationship between $\Lambda_{8}$ and river discharge $(p>0.05)$, the highest value occurred during peak discharge in April 1999-which corresponded to the highest observed $\mathrm{C} / \mathrm{N}$ value of 17.41 . The $\Lambda_{8}$ values on the shelf ranged from 0.68 to 1.36 (mean $=0.54 \pm 0.30)$ and were significantly lower $(p<0.05)$ than the average value for lower river sediments. The range of $\mathrm{S} / \mathrm{V}$ (syringyl/vanillyl) and $\mathrm{C} / \mathrm{V}$ (cinnamyl/vanillyl) ratios on the shelf, 0.11 to 0.95 and 0.01 to 0.08 , respectively, were similar to that found in the lower river. These low $\mathrm{C} / \mathrm{V}$ ratios are indicative a mixture of woody and non-woody carbon sources. Recent work by Goni et al. [Nature 389 (1997) 275; Geochim. Cosmochim. Acta 62 (1998) 3055], which did not include sampling transects within the primary dispersal system of the Mississippi River, showed a non-woody vascular plant signature on the Louisiana shelf. This suggests that riverine-derived woody tissues preferentially settle out of the water column, in the lower river and inner shelf, prior to the selective dispersal of $\mathrm{C}_{3}$ versus $\mathrm{C}_{4}$ non-woody materials in other regions the shelf and slope. This works further demonstrates the importance of differential settlement of particles, sampling location within the dispersal system, and river discharge, when examining biogeochemical cycles in river-dominated margins. (C) 2002 Elsevier Science B.V. All rights reserved.
\end{abstract}

Keywords: Organic carbon; Sedimentation; Transport

\section{Introduction}

${ }^{*}$ Corresponding author. Tel.: +1-504-862-8285; fax: +1-504862-8794.

E-mail address: tbianch@tulane.edu (T.S. Bianchi).
Rivers are the major conduits for the transport of water, salt, organic matter, and mineral matter from land to sea. Large rivers may play a disproportionately 
important role in this terrestrial-marine linkage. The world's 10 largest rivers transport approximately $40 \%$ of the fresh water and particulate materials entering the ocean (Milliman, 1991). Despite the importance of sedimentary carbon, the fate of organic matter in continental shelf environments is not completely understood (Berner, 1982; Hedges and Keil, 1995). This lack of understanding largely results from the high degree of spatial and temporal variability in sources of organic carbon at this boundary-such as primary production by phytoplankton and discharge of terrigenous organic carbon by rivers and local wetlands.

Terrestrial inputs of organic carbon to continental margin waters of the northern Gulf of Mexico (GOM) are high compared with other coastal margins of the US because of significant discharges from one of the world's largest river systems - the combined inputs of the Atchafalaya and Mississippi Rivers (Hedges and Parker, 1976; Malcolm and Durum, 1976; Eadie et al., 1994; Trefry et al., 1994). Earlier studies showed significant depletion of $\delta^{13} \mathrm{C}$ in bulk carbon in sediments near regions of the Mississippi Plume and northwestern $\mathrm{GOM}$-indicative of $\mathrm{C}_{3}$ plant-derived riverine sources (Sackett and Thompson, 1963; Hedges and Parker, 1976; Gearing et al., 1977). However, recent work has suggested that much of the terrestrially-derived organic matter delivered to the shelf is from $\mathrm{C}_{4}$ and $\mathrm{C}_{3}$ plants materials from eroded soils in the northwestern grasslands of the Mississippi River drainage basin (Goni et al., 1997, 1998; Onstad et al., 2000). Moreover, it is believed that $\mathrm{C}_{4}$ carbon is transported greater distances offshore in the GOM than $\mathrm{C}_{3}$ carbon because $\mathrm{C}_{4}$ carbon is associated with a finer size fraction of sediments (Goni et al., 1998). Other work has also shown that non-woody angiosperms are the dominant form of vascular plant material being transported to sediments in deeper regions of the GOM (Texas slope) (Bianchi et al., 1997). Thus, the general paradigm is that much of the terrestrially-derived organic matter from the Mississippi River transported offshore is $\delta^{13} \mathrm{C}$-enriched, associated with fine-grained sediments, and has a $\mathrm{C}_{4}$ signature (Goni et al., 1997, 1998; Onstad et al., 2000). Studies off the Washington coast have also shown that hydrodynamic sorting of river-derived particulates resulted in the deposition of a greater proportion of lignin as larger discrete fragments of vascular plant detritus in nearshore sediments than in the lignin-containing fine sediments deposited off- shore (Prahl et al., 1994; Ertel and Hedges, 1985). To better understand the selective transport mechanisms of organic carbon at the river-coastal boundary, it is necessary to examine the storage characteristics of the lower river and particle removal processes within the riverine dispersal system on the adjacent shelf.

The seasonal storage and remobilization of sediments in rivers is a worldwide phenomenon that has been observed and described for rivers ranging in size from small streams (Emmett et al., 1983; Meade et al., 1990) to the Amazon, the world's largest river (Meade et al., 1985). For example, this phenomenon has been well documented for the lower $500 \mathrm{~km}$ of the Mississippi River (Meade and Parker, 1985; Demas and Curwick, 1988), where, in general, sediments are deposited on the riverbed during low discharge stages (water discharge rates below $14,000 \mathrm{~m}^{3} \mathrm{~s}^{-1}$ ), and subsequently resuspended during high discharge stages (water discharge rates above $20,000 \mathrm{~m}^{3} \mathrm{~s}^{-1}$ ). Because of the extensive levee system, there are essentially no inputs or outlets in the lower $500-\mathrm{km}$ stretch of the river from Tarbert Landing (just below the Control structure and diversion of the Atchafalya River: $340 \mathrm{~km}$ upriver from New Orleans) to Venice (near the mouth of the river: $135 \mathrm{~km}$ downriver from New Orleans).

While there has been considerable interest in characterizing organic carbon inputs in river-dominated margins, previous studies have been based on data collected during one or two brief sampling periods in large river systems. As valuable as these studies are, they yield only a brief glimpse at these complex and dynamic systems. Moreover, much of the work in larger rivers has been focused on characterizing the suspended particles in rivers, while others have focused principally on sediments and particulates of the adjacent shelf. The boundary between the river proper (lower river) and shelf is a dynamic region where hydrodynamic sorting, seasonal variability in storage and diagenesis of organic matter in sediments, and flocculation processes can influence the composition of sedimentary organic carbon transported to the shelf and beyond. Moreover, the frequent resuspension of sediments across these shelves typically produces a fluidized-bed in the surface sediments that has been shown to be very efficient in the remineralization of organic matter (Aller, 1998). In this study, we examined the temporal and spatial variability of terrestrial organic carbon sources in lower Mississippi River and 
Louisiana shelf sediments to further understand the sorting dynamics and selective transport of vascular plant materials within the riverine dispersal system, as they relate to processes recently discussed by Goni et al. $(1997,1998)$ and Onstad et al. (2000).

\section{Materials and methods}

\subsection{Lower Mississippi river}

Globally, the Mississippi River has the third largest drainage basin area, the sixth largest water discharge, and the seventh largest suspended load among world rivers (Milliman, 1991). Approximately $60 \%$ of the total suspended matter and $66 \%$ of the total dissolved solids transported from the conterminous US to the ocean is carried by the Mississippi (Presley et al., 1980). Stream flow in the lower Mississippi River is affected by a diversion of $30 \%$ of the total flow to the Atchafalaya River through the Old River control structure, just above Tarbert Landing. Below Tarbert Landing, channel cross-sectional area generally increases with downstream distance. The mean depth of flow varies from $\sim 6$ to $60 \mathrm{~m}$. Saltwater intrusion into the lower section of the river is negligible except at very low discharge stages. For flow greater than $5000 \mathrm{~m}^{3} \mathrm{~s}^{-1}$, the salt-wedge is restricted to an area below Venice (Wells, 1980). Despite temporal variations due to turbulence, the flow is nearly uniformly distributed laterally in the study area for all flow regimes (Demas and Curwick, 1988). The transit time for river water in the lower $500 \mathrm{~km}$ of the Mississippi ranges from 2 to 5 days, depending on discharge (Pereira and Hostettler, 1993).

\subsection{Study site and sampling}

Sediments were collected at two stations (Sta. 1 and 2) in the lower river and the inner Louisiana shelf (Sta. 3 and 4), onboard the R/V Pelican, using a boxcorer $(50 \times 50 \times 50 \mathrm{~cm})$ during 10 cruises over $1998-$ 2000 (Figs. 1 and 2). In some cases, we were not able to sample all four stations during each cruise due to weather conditions that prevented us from box-coring on the shelf. Stations 1 and 2 are approximately 126 and $18 \mathrm{~km}$ upriver from the mouth of the Mississippi River and have water depths of 15 and $9 \mathrm{~m}$, respec- tively. These locations in the river represent areas where we could find fine-grained sediments throughout most of the year. An initial grab-sample survey of surface sediments in the lower river revealed that there is significant heterogeneity in the lower river and that much of the river bottom is composed of coarse sandy sediments during high flow periods. Stations 3 and 4 are located on the inner Louisiana shelf and within the proximal portion of the riverine dispersal system; the water depths at these stations are 50 and $30 \mathrm{~m}$, respectively.

The duration of the sampling period allowed for a wide range of variation in Mississippi River discharge rates (ca. 4900-26,000 $\mathrm{m}^{3} \mathrm{~s}^{-1}$ ) (Fig. 2); all discharge rates were obtained from the Tarbert Landing GaugeStation (340 km upriver from New Orleans) operated by the US Army Corps of Engineers and US Geological Survey. The low flow periods reached 20 -year record lows $\left(<5000 \mathrm{~m}^{3} \mathrm{~s}^{-1}\right)$ during this study. Consequently, the salt-wedge also reached further upriver and at certain times during low flow periods salt water extended just south of Station 1.

Once box-cores were collected, sub-cores were taken from within and sectioned into centimeter intervals onboard in a nitrogen-filled glove-box. Sediment samples from each depth were homogenized then stored frozen onboard $\left(-20{ }^{\circ} \mathrm{C}\right)$, and transferred to a $-80{ }^{\circ} \mathrm{C}$ freezer in the laboratory prior to bulk and molecular carbon analyses.

Water column samples were collected in surface and bottom waters and analyzed for total particulate organic carbon and total nitrogen (POC and TN) analyses and suspended particle matter (SPM). Samples were collected using a Sea-bird Electronics 911 CTD with a 125 liter Niskin bottle rosette, filtered (GFF filter, $25-\mathrm{mm}$ diam., nominal pore size $0.7 \mu \mathrm{m}$ ), and stored frozen.

\subsection{Carbon and nitrogen analysis}

Frozen sediment samples were oven-dried at $50{ }^{\circ} \mathrm{C}$ for $24 \mathrm{~h}$. Approximately $100 \mathrm{mg}$ of dried sediment were transferred to a small vial, and acidified with acid vapor in a dessicator for over $48 \mathrm{~h}$ (Hedges and Stern, 1984). After acidification, samples were then oven-dried at $50{ }^{\circ} \mathrm{C}$ for over $12 \mathrm{~h}$. Carbon (C) and nitrogen $(\mathrm{N})$ analyses were conducted on an Elemental Analyzer (EA1108, FISONS Instruments) with duplicate analysis for all samples. 


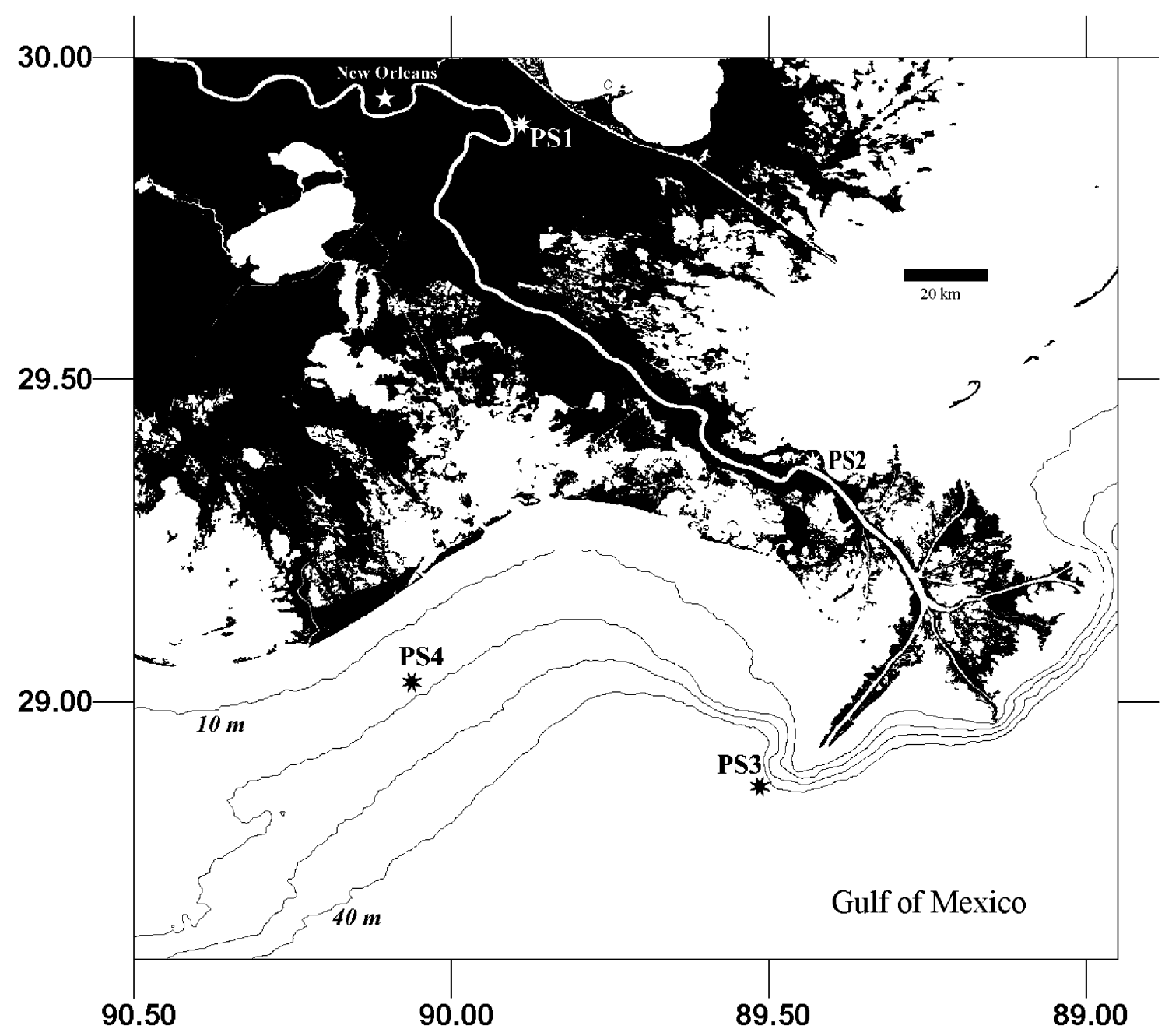

Fig. 1. Map showing four sampling locations in the lower Mississippi and Louisiana shelf.

\subsection{Stable carbon isotopes}

Stable carbon analyses of sedimentary organic carbon were made on acidified samples using isotope ratio-mass spectrometry according to Fry et al (1992). Samples were analyzed at University of California at Davis; for details see http://stableisotopefacility.ucdavis.edu/.

\subsection{Lignin-phenol analyses}

Lignin-phenols were extracted according to the method of Hedges and Ertel (1982). Sediments were placed in Monel mini-bombs with $7 \mathrm{ml}$ of $2 \mathrm{~N}$ $\mathrm{NaOH}, 1$-g $\mathrm{CuO}, 50 \mathrm{mg}$ of $\mathrm{Fe}\left(\mathrm{NH}_{4}\right)_{2}\left(\mathrm{SO}_{4}\right)_{2} \cdot 6 \mathrm{H}_{2} \mathrm{O}$ in a $\mathrm{N}_{2}(\mathrm{~g})$-filled glove box. The reaction product from each sample was spiked with $100 \mu$ of ethylvanillin $\left(1 \mathrm{mg} \mathrm{ml}^{-1}\right.$ in $\left.0.1 \mathrm{~N} \mathrm{NaOH}\right)$ as an internal standard, then acidified to a $\mathrm{pH}=1$ prior to extraction with ethyl ether (freshly distilled) over an aqueous solution of nanopure water and $\mathrm{Fe}\left(\mathrm{NH}_{4}\right)_{2}$ $\left(\mathrm{SO}_{4}\right)_{2} \cdot 6 \mathrm{H}_{2} \mathrm{O}$. Organic extracts were filtered over anhydrous $\mathrm{Na}_{2} \mathrm{SO}_{4}$ and then concentrated to a thin film in glass tubes. Samples were stored at $-20{ }^{\circ} \mathrm{C}$ prior to being derivatized and injected on a gas chromatograph. 


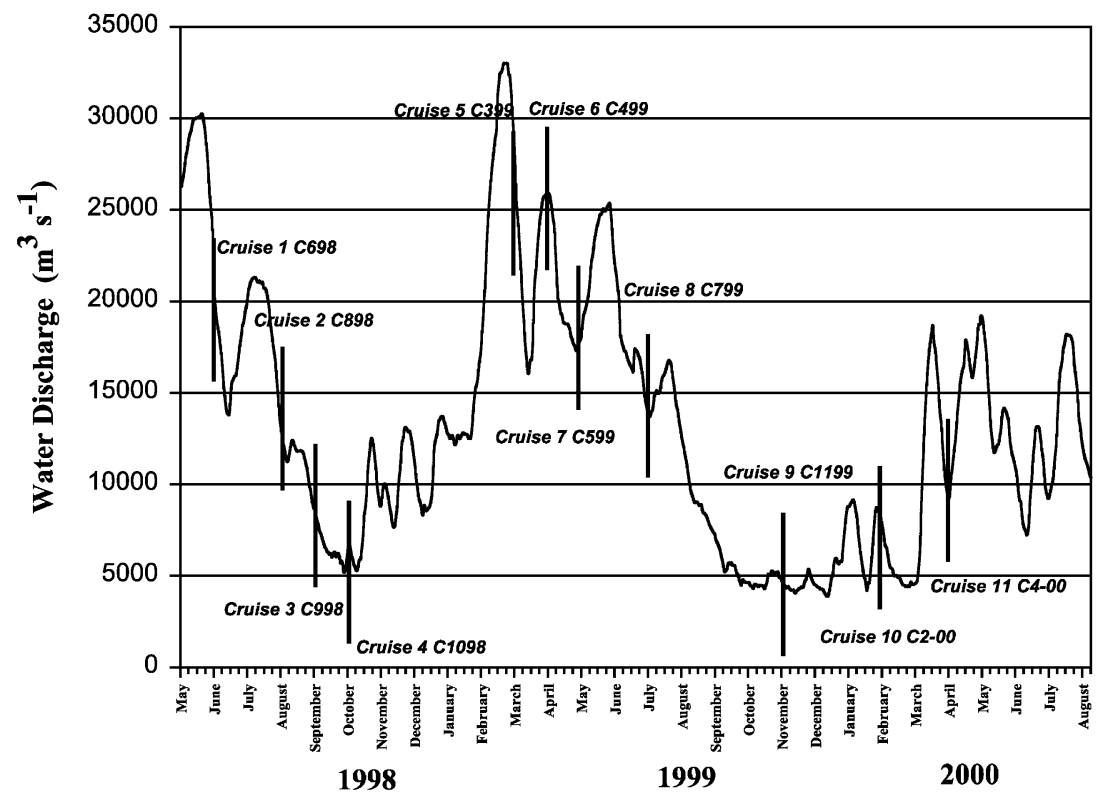

Fig. 2. Sampling dates of eleven cruises relative to seasonal changes in Mississippi River discharge $\left(\mathrm{m}^{3} \mathrm{~s}^{-1}\right)$ at Tarbert Landing in $1998-2000$, courtesy of USGS. Data from cruise 1 was not included in this paper.

Lignin oxidation products (LOPs) in the residual extract were analyzed as trimethylsilyl derivatives (BSTFA reagent, Regis Chemical) by adding $50 \mu \mathrm{l}$ of a pyridine/BSTFA $(1: 1-\mathrm{v} / \mathrm{v})$ solution. Ligninphenols were analyzed using a Hewlett Packard 6890 Series Gas Chromatograph/Mass Spectrometric Detector (GC/MS) in the selective ion monitoring mode with a $30 \mathrm{~m} \times 0.25 \mathrm{~mm}$ i.d. $\times 1 \mu \mathrm{m}$ film thickness DB-5MS capillary column (J \& W Scientific). The GC/MS conditions for sample analysis were as follows: injector and detector temperatures, $300{ }^{\circ} \mathrm{C}$; split injection (1/50) with $1.5 \mathrm{~cm}^{3} \mathrm{~min}^{-1}$ of ultra-high purity $\mathrm{He}$ as the carrier gas; initial column temperature $100{ }^{\circ} \mathrm{C}$ increased to $270{ }^{\circ} \mathrm{C}$ at $4{ }^{\circ} \mathrm{C} \mathrm{min}{ }^{-1}$ followed by a 16-min isothermal hold. Gas chromatograph response was generally linear over a range of concentrations for each LOP in a mixed LOP standard. Thus, a one-point calibration curve using a specific concentration of the mixed LOP standard was used on a daily basis to confirm retention times, mass spectra, and response factors for each target LOP. Based on GC/ MS daily response over 1 week, analytical precision for individual LOP monomers in the mixed response factor standard ranged from a minimum of $1 \%$ for VAL to a maximum of $24 \%$ for CAD.

\subsection{Radionuclides}

The $\mathrm{Pb}-210$ activities were determined by alpha particle spectrometry methods. Polonium-210, the radiometric granddaughter of $\mathrm{Pb}-210$, was counted after methods described in McKee et al. (1983), DeMaster et al. (1985) and Nittrouer et al. (1979). A wet weight/dry weight ratio was determined for each sample by drying at $55{ }^{\circ} \mathrm{C}$ to a constant weight. Each sample was spiked with a Po-209 tracer (man-made) to determine and correct for chemical yield and counting efficiency. Sediments are leached with nitric and hydrochloric acids in a Teflon microwave digestion bomb. Polonium was spontaneously electroplated onto pre-cleaned nickel planchets. The polonium/lead 210 concentrations are measured using silicon barrier detectors and an alpha spectrometer. A procedural blank is included with each set of core sections and reported data is blank corrected. Replicate analyses are conducted on at least one sample per core. Corrections are made for radioactive decay between times of collection and radiochemical counting.

Concentrations of Be-7 were analyzed by gamma ray spectrometry (PGT intrinsic germanium, planar type detector) and multi-channel analyzer. Counting 
Table 1

Suspended particulate matter (SPM), percent organic carbon $(\% \mathrm{OC})$, percent total nitrogen $(\% \mathrm{TN})$, and molar carbon to nitrogen ratios $(\mathrm{C} / \mathrm{N})$ of suspended particulates in the lower Mississippi River and Louisiana shelf in 1998-2000

\begin{tabular}{|c|c|c|c|c|c|c|c|}
\hline Station & Date & $\begin{array}{l}\text { Water } \\
\text { depth }(\mathrm{m})\end{array}$ & $\begin{array}{l}\text { Salinity } \\
\text { (p.s.u) }\end{array}$ & $\begin{array}{l}\text { SPM } \\
\left(\mathrm{mg} \mathrm{l}^{-1}\right)\end{array}$ & $\begin{array}{l}\% \\
\mathrm{OC}\end{array}$ & $\begin{array}{l}\% \\
\mathrm{TN}\end{array}$ & $\mathrm{C} / \mathrm{N}$ \\
\hline $\begin{array}{l}\text { 1- Lower } \\
\text { river }\end{array}$ & $4 / 99$ & 0.5 & 0 & 82.0 & 2.3 & 0.2 & 13 \\
\hline 1 & $4 / 99$ & 15.0 & 0 & 101.0 & 2.4 & 0.3 & 9.3 \\
\hline 1 & $5 / 99$ & 0.5 & 0 & 225.0 & 2.3 & 0.2 & 13.4 \\
\hline 1 & $5 / 99$ & 15.0 & 0 & 210.3 & 2.4 & 0.2 & 政 \\
\hline 1 & $11 / 99$ & 0.5 & 0 & 14.0 & 2.1 & 0.4 & 6.1 \\
\hline 1 & $11 / 99$ & 17.0 & 0 & 14.0 & 3.0 & 0.4 & 8.7 \\
\hline Mean & & $\begin{array}{l}\text { Surface } \\
\text { waters }\end{array}$ & & 107.7 & 2.2 & 0.3 & 11.0 \\
\hline SD & & & & 100.0 & 0.1 & 0.1 & 4.2 \\
\hline Mean & & $\begin{array}{l}\text { Bottom } \\
\text { Waters }\end{array}$ & & 108.3 & 0.3 & 0.3 & 10.7 \\
\hline SD & & & & 98.2 & 0.1 & 0.1 & 2.9 \\
\hline $\begin{array}{l}2 \text { - Lower } \\
\text { river }\end{array}$ & $4 / 99$ & 0.5 & 0 & 70.0 & 2.7 & 0.3 & 0.5 \\
\hline 2 & $4 / 99$ & 9.0 & 0 & 90.0 & 2.5 & 0.3 & 9.7 \\
\hline 2 & $5 / 99$ & 0.5 & 0 & 174.4 & 2.5 & 0.2 & 14.6 \\
\hline 2 & $5 / 99$ & 6.0 & 0 & 134.2 & 2.6 & 0.3 & 10.1 \\
\hline 2 & $7 / 99$ & 0.5 & 0 & 131.4 & 1.3 & 0.3 & 5.1 \\
\hline 2 & $7 / 99$ & 8.0 & 0 & 414.0 & 0.9 & 0.2 & 5.2 \\
\hline Mean & & $\begin{array}{l}\text { Surface } \\
\text { waters }\end{array}$ & & 125.0 & 2.2 & 0.3 & 10.0 \\
\hline SD & & & & 52.3 & 0.8 & 0.06 & 4.8 \\
\hline Mean & & $\begin{array}{l}\text { Bottom } \\
\text { Waters }\end{array}$ & & 213.0 & 2.0 & 0.3 & 8.4 \\
\hline SD & & & & 175.7 & 0.9 & 0.06 & 2.7 \\
\hline $\begin{array}{c}3 \text { - Inner } \\
\text { shelf }\end{array}$ & $9 / 98$ & 0.5 & 3.6 & 14.2 & NA & NA & NA \\
\hline 3 & $9 / 98$ & 50.0 & 35.2 & 25.5 & NA & NA & NA \\
\hline 3 & $7 / 99$ & 0.5 & 5.0 & 27.0 & 2.4 & 0.3 & 9.4 \\
\hline 3 & $7 / 99$ & 48.0 & 36.0 & 37.0 & 0.4 & 0.02 & 23.3 \\
\hline 3 & $4 / 00$ & 2.0 & 22.1 & 30.2 & 1.9 & 0.3 & 7.4 \\
\hline 3 & $4 / 00$ & 52.0 & 33.4 & 21.7 & 0.2 & 0.02 & 11.7 \\
\hline Mean & & $\begin{array}{l}\text { Surface } \\
\text { waters }\end{array}$ & & 23.8 & 2.2 & 0.3 & 8.4 \\
\hline SD & & & & 8.5 & 0.4 & 0 & 1.4 \\
\hline Mean & & $\begin{array}{l}\text { Bottom } \\
\text { Waters }\end{array}$ & & 28.1 & 0.3 & 0.02 & 17.5 \\
\hline SD & & & & 8.0 & 0.1 & 0 & 8.2 \\
\hline $\begin{array}{c}\text { 4-Inner } \\
\text { shelf }\end{array}$ & $4 / 99$ & 0.5 & 28.0 & 52.5 & 2.0 & 0.3 & 7.8 \\
\hline 4 & $4 / 99$ & 27.0 & 36.0 & 75.7 & 0.3 & 0.02 & 17.5 \\
\hline 4 & $7 / 99$ & 0.5 & 16.0 & 31.3 & 7.8 & 1.5 & 6.1 \\
\hline 4 & $7 / 99$ & 28.0 & 35.0 & 36.3 & 0.7 & 0.2 & 4.1 \\
\hline 4 & $4 / 00$ & 2.0 & 31.2 & 21.3 & 2.6 & 0.4 & 7.6 \\
\hline 4 & $4 / 00$ & 25.0 & 30.9 & 13.1 & 0.5 & 0.04 & \\
\hline
\end{tabular}

Table 1 (continued)

\begin{tabular}{|c|c|c|c|c|c|c|c|}
\hline Station & Date & $\begin{array}{l}\text { Water } \\
\text { depth }(\mathrm{m})\end{array}$ & $\begin{array}{l}\text { Salinity } \\
\text { (p.s.u) }\end{array}$ & $\begin{array}{l}\text { SPM } \\
\left(\mathrm{mg} \mathrm{1}^{-1}\right)\end{array}$ & $\begin{array}{l}\% \\
\text { OC }\end{array}$ & $\begin{array}{l}\% \\
\mathrm{TN}\end{array}$ & $\mathrm{C} / \mathrm{N}$ \\
\hline Mean & & $\begin{array}{l}\text { Surface } \\
\text { waters }\end{array}$ & & 35.0 & 4.1 & 0.7 & 7.1 \\
\hline SD & & & & 16.0 & 3.2 & 0.6 & 0.9 \\
\hline Mean & & $\begin{array}{l}\text { Bottom } \\
\text { Waters }\end{array}$ & & 42.0 & 0.5 & 0.1 & 12.0 \\
\hline SD & & & & 32.0 & 0.2 & 0.1 & 7.1 \\
\hline
\end{tabular}

efficiencies were determined by a mixed gamma source (IAEA-300) containing gamma emitters over a range of energies $(46.5-1460 \mathrm{keV})$. The activity of Be-7 for each sampling period was decay-corrected to the date of sampling.

\subsection{Statistical analyses}

All statistical analyses were conducted with Statgraphics or Sigmaplot. Simple regression analyses, paired or non-paired $t$-tests, and correlation analysis

Table 2

Sedimentation rates at the four locations in the lower Mississippi River and Louisiana shelf - cores were collected in 1998-2000

\begin{tabular}{llll}
\hline Station & Date & $\mathrm{Pb}-210\left(\mathrm{~cm} \mathrm{year}^{-1}\right)$ & Notes \\
\hline 1 - Lower river & $8 / 98$ & $>10$ & $\mathrm{BC}$ \\
1 & $10 / 98$ & $>10$ & $\mathrm{BC}$ \\
1 & $3 / 99$ & $>10$ & $\mathrm{BC} ; \mathrm{Be}-7$ to $>27 \mathrm{~cm}$ \\
1 & $4 / 99$ & $>10$ & $\mathrm{BC} ; \mathrm{Be}-7$ to $>21 \mathrm{~cm}$ \\
1 & $5 / 99$ & $>10$ & $\mathrm{BC} ; \mathrm{Be}-7$ to $>46 \mathrm{~cm}$ \\
1 & $11 / 99$ & $>10$ & $\mathrm{BC} ; \mathrm{Be}-7$ to $>39 \mathrm{~cm}$ \\
1 & $2 / 00$ & $\mathrm{NA}$ & \\
& & & \\
2 - Lower river & $9 / 98$ & & $\mathrm{BC} ; \mathrm{Be}-7$ to $>40 \mathrm{~cm}$ \\
2 & $4 / 99$ & $>10$ & $\mathrm{BC} ; \mathrm{Be}-7$ to $>46 \mathrm{~cm}$ \\
2 & $5 / 99$ & $>10$ & $\mathrm{BC} ; \mathrm{Be}-7$ to $>40 \mathrm{~cm}$ \\
2 & $7 / 99$ & $>10$ & \\
2 & $2 / 00$ & $\mathrm{NA}$ & $\mathrm{BC} ; \mathrm{Be}-7$ to $>45 \mathrm{~cm}$ \\
& & & $\mathrm{BC} ; \mathrm{Be}-7$ to $>42 \mathrm{~cm}$ \\
$3-$ Inner shelf & $9 / 98$ & $>10$ & $\mathrm{KC}$ \\
3 & $7 / 99$ & $>10$ & $\mathrm{BC}$ \\
3 & $4 / 00$ & 13.5 & $\mathrm{BC}$ \\
$4-$ Inner shelf & $4 / 99$ & 0.13 & $\mathrm{BC}$ \\
4 & $7 / 99$ & 0.13 & \\
4 & $4 / 00$ & 0.11 & \\
\hline NA=not available. & & \\
$\mathrm{BC}=$ box-core $(\sim 50 \mathrm{~cm}) ; \mathrm{KC}=$ kasten core $(\sim 2 \mathrm{~m})$.
\end{tabular}


Table 3

Percent fines, organic carbon $(\% \mathrm{OC})$ and nitrogen $(\% \mathrm{TN})$ abundances, molar $\mathrm{C} / \mathrm{N}$ ratios, stable carbon $\left({ }^{13} \mathrm{C}\right)$ isotopic ratios in Surface $(0-2 \mathrm{~cm})$ sediments from the lower Mississippi River and Louisiana shelf in 1998-2000

\begin{tabular}{|c|c|c|c|c|c|c|}
\hline Station & Date & $\begin{array}{l}\text { \%Fines } \\
(<63 \mathrm{um})\end{array}$ & $\% \mathrm{OC}$ & $\% \mathrm{TN}$ & $\mathrm{C} / \mathrm{N}$ & $\delta^{13} \mathrm{C}$ \\
\hline 1-Lower river & $8 / 98$ & NA & 1.0 & 0.1 & 11.7 & -23.1 \\
\hline 1 & $10 / 98$ & NA & 1.4 & 0.1 & 12.3 & -23.5 \\
\hline 1 & $3 / 99$ & NA & 0.8 & 0.1 & 15.5 & -24.5 \\
\hline 1 & $4 / 99$ & 68.3 & 0.5 & 0.03 & 18.7 & -24.6 \\
\hline 1 & $5 / 99$ & 84.9 & 1.1 & 0.1 & 13.3 & -22.8 \\
\hline 1 & $11 / 99$ & 81.7 & 1.9 & 0.2 & 12.1 & -22.8 \\
\hline 1 & $2 / 00$ & 92.7 & 1.8 & 0.2 & 10.5 & -24.7 \\
\hline Mean & & & 1.2 & 0.1 & 13.4 & -23.7 \\
\hline SD & & & 0.5 & 0.06 & 2.8 & 0.80 \\
\hline 2-Lower river & $9 / 98$ & NA & 1.5 & 0.2 & 11.4 & -22.6 \\
\hline 2 & $4 / 99$ & 56.1 & 0.7 & 0.1 & 13.9 & -24.6 \\
\hline 2 & $5 / 99$ & 55.0 & 0.9 & 0.1 & 12.0 & -21.5 \\
\hline 2 & $7 / 99$ & 91.9 & 1.5 & 0.1 & 12.8 & -21.9 \\
\hline 2 & $2 / 00$ & 99.3 & 1.6 & 0.2 & 10.7 & -22.8 \\
\hline Mean & & & 1.2 & 0.1 & 12.2 & -22.7 \\
\hline SD & & & 0.4 & 0.05 & 1.3 & 1.0 \\
\hline 3 -inner shelf & $9 / 98$ & NA & 0.9 & 0.1 & 10.0 & -21.7 \\
\hline 3 & $7 / 99$ & NA & 1.1 & 0.1 & 11.7 & -22.5 \\
\hline 3 & $4 / 00$ & 93.9 & 1.0 & 0.1 & 11.1 & -21.4 \\
\hline Mean & & & 1.0 & 0.1 & 10.8 & -21.9 \\
\hline SD & & & 0.1 & 0.01 & 1.0 & 0.50 \\
\hline 4 -Inner shelf & $4 / 99$ & NA & 0.9 & 0.1 & 9.6 & -21.6 \\
\hline 4 & $7 / 99$ & NA & 0.8 & 0.1 & 9.4 & -21.4 \\
\hline 4 & $4 / 00$ & 97.1 & 0.7 & 0.1 & 11.0 & -21.2 \\
\hline Mean & & & 0.8 & 0.1 & 9.9 & -21.4 \\
\hline SD & & & 0.08 & 0.01 & 0.7 & 0.15 \\
\hline
\end{tabular}

$\mathrm{NA}=$ not available; $\mathrm{SD}=$ standard deviation.

were used to test for significant differences and relationships among LOP concentrations and with other measured parameters. Significance was defined at the 95\% confidence level $(p<0.05)$.

\section{Results}

\subsection{Water column particulates}

Ranges of total suspended particulate matter (SPM) at Stations $1\left(14-225 \mathrm{mg} \mathrm{l}^{-1}\right)$ and $2\left(70-414 \mathrm{mg}^{-1}\right)$ varied considerably over the different periods of river discharge (Table 1). The lowest observed SPM value was found at Station 1 during the lowest flow period in November 1999. Although SPM showed significant temporal variability, the ranges of percent organic carbon $(\% \mathrm{OC})$ and total nitrogen $(\% \mathrm{TN})$ of SPM at Stations 1 (2.1-3.0 and 0.2-0.4) and 2 (0.9-2.7 and $0.2-0.3$ ), respectively, did not vary as much (Table 1 ). The range of $\mathrm{C} / \mathrm{N}$ ratios at Stations 1 and 2 were $6.1-$ 13.4 and 5.1-15.0, respectively (Table 1). Suspended particulate matter on shelf stations 3 and 4 showed no consistent differences between surface and bottom waters and ranged from 14.2 to $37 \mathrm{mg} \mathrm{l}^{-1}$ and 13.1 to $75.7 \mathrm{mg} \mathrm{l}^{-1}$, respectively. It is interesting to note that the $\mathrm{C} / \mathrm{N}$ ratios of particulates in bottom waters on the shelf stations was in most cases significantly higher than in surface waters - indicating possible resuspension of diagenetically altered sediments as well as inputs of terrestrially-derived materials from the river and local wetlands.

\subsection{Sedimentation rates}

Sedimentation rates at the two river stations (Stations 1 and 2) were very high $\left(>10 \mathrm{~cm}_{\text {year }}{ }^{-1}\right)$ for all cruises. Excess Pb-210 (22.3-year half-life) was present at the bottom of all box-cores collected. With the observed excess $\mathrm{Pb}-210$ activities and the associated analytical error $(\sim 5 \%)$, an activity change due to

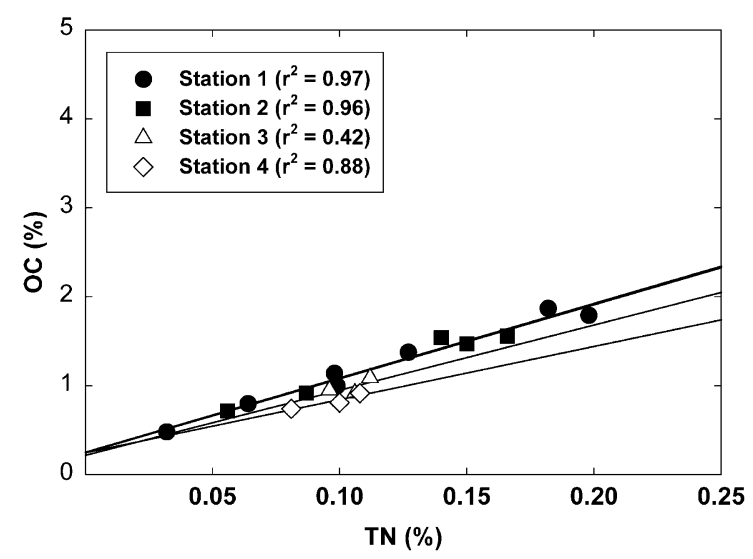

Fig. 3. Regression of percent organic carbon versus total nitrogen in surface sediments $(0-2 \mathrm{~cm})$ collected from four stations in the lower Mississippi River (Stations 1 and 2) and Louisiana shelf (Stations 3 and 4) in 1998-2000. 
decay within a 5-year period is easily detectable. Therefore, no discernable excess $\mathrm{Pb}-210$ decay in the $40-50-\mathrm{cm}$ cores indicates steady state sedimentation rates of greater than $10 \mathrm{~cm}_{\text {year }}{ }^{-1}$. In many cases (Table 2), Be-7 (53-day half-life) was also determined via gamma spectrometry. In most cases, Be-7 was measurable through out the length of the box-core, indicating that short-term deposition rates are tens of centimeters per month during these depositional periods of river discharge.

Sedimentation rates at the two shelf stations (Stations 3 and 4) decreased with distance from the river mouth. At Station 3, excess $\mathrm{Pb}-210$ was detected throughout the length of the box-core in September
1998 and July 1999. Be-7 was also present throughout the box-core during those two sampling periods. As discussed above, this leads to conservative estimates of $>10 \mathrm{~cm}_{\text {year }}{ }^{-1}$, with seasonal deposition rates even greater. The excess $\mathrm{Pb}-210$ profile from a 2-m Kasten core taken in April 2000, yields a sedimentation rate of $13.5 \mathrm{~cm}$ year $^{-1}$ on a decadal time scale. Of the two shelf stations, Station 4 is farthest from the river mouth but still within the primary riverine dispersal system. Sedimentation rates drop off sharply between Station $3\left(>10 \mathrm{~cm}_{\text {year }}{ }^{-1}\right)$ and Station $4(\sim 0.12 \mathrm{~cm}$ year $\left.^{-1}\right)$, consistent with observations within the dispersal systems in other river-dominated ocean margins (e.g., DeMaster et al., 1985).

Table 4

Lignin-phenol concentrations, interclass ratios, and yields in lower Mississippi River and Louisiana shelf surface $(0-2 \mathrm{~cm})$ sediments (mg 100 $\mathrm{mg} \mathrm{OC}^{-1}$ ) collected in $1998-2000$

\begin{tabular}{|c|c|c|c|c|c|c|c|c|c|c|c|c|c|c|}
\hline Station & Date & VAL & VON & VAD & SAL & SON & SAD & FAD & CAD & $\mathrm{C} / \mathrm{V}$ & $\mathrm{S} / \mathrm{V}$ & $(\mathrm{Ad} / \mathrm{Al})_{\mathrm{v}}$ & $(\mathrm{Ad} / \mathrm{Al})_{\mathrm{s}}$ & $\Lambda_{8}$ \\
\hline 1-Lower river & $8 / 98$ & 0.62 & 0.19 & ND & 0.58 & 0.26 & ND & ND & ND & NQ & 1.17 & NQ & NQ & 1.66 \\
\hline 1 & $10 / 98$ & 0.33 & 0.18 & ND & 0.12 & 0.10 & ND & ND & ND & NQ & 0.42 & NQ & NQ & 0.72 \\
\hline 1 & $3 / 99$ & 0.79 & 0.22 & ND & 0.77 & 0.23 & ND & ND & ND & NQ & 0.99 & NQ & NQ & 2.00 \\
\hline 1 & $4 / 99$ & 0.89 & 0.23 & 0.27 & 0.73 & 0.23 & 0.19 & 0.02 & 0.03 & 0.03 & 0.83 & 0.30 & 0.27 & 2.58 \\
\hline 1 & $5 / 99$ & 0.59 & 0.18 & ND & 0.43 & 0.16 & ND & ND & ND & NQ & 0.78 & NQ & NQ & 1.36 \\
\hline 1 & $11 / 99$ & 0.33 & 0.12 & 0.14 & 0.55 & 0.19 & 0.13 & 0.01 & 0.02 & 0.05 & 1.47 & 0.43 & 0.24 & 1.48 \\
\hline 1 & $2 / 00$ & 0.64 & 0.21 & 0.05 & 0.50 & 0.23 & 0.05 & ND & 0.02 & 0.02 & 0.87 & 0.08 & 0.10 & 1.69 \\
\hline Mean & & 0.60 & 0.19 & 0.15 & 0.53 & 0.20 & 0.12 & 0.02 & 0.02 & 0.03 & 0.93 & 0.27 & 0.20 & 1.64 \\
\hline SD & & 0.20 & 0.03 & 0.09 & 0.20 & 0.05 & 0.06 & 0.01 & 0.00 & 0.01 & 0.30 & 0.14 & 0.07 & 0.53 \\
\hline 2-Lower river & 9/98 & 0.56 & 0.17 & ND & 0.46 & 0.19 & ND & ND & ND & NQ & 0.89 & NQ & NQ & 1.39 \\
\hline 2 & $4 / 99$ & 0.98 & 0.31 & 0.47 & 1.01 & 0.35 & 0.44 & 0.07 & 0.09 & 0.09 & 1.03 & 0.48 & 0.43 & 3.72 \\
\hline 2 & $5 / 99$ & 0.34 & 0.25 & 0.02 & 0.60 & 0.34 & 0.01 & ND & ND & NQ & 1.59 & 0.06 & 0.02 & 1.56 \\
\hline 2 & $7 / 99$ & 0.88 & 0.21 & 0.03 & 0.62 & 0.23 & 0.07 & ND & 0.08 & 0.07 & 0.82 & 0.04 & 0.12 & 2.11 \\
\hline 2 & $2 / 00$ & 0.37 & 0.14 & 0.04 & 0.26 & 0.15 & 0.09 & ND & 0.08 & 0.15 & 0.92 & 0.10 & 0.35 & 1.13 \\
\hline Mean & & 0.63 & 0.22 & 0.14 & 0.59 & 0.25 & 0.15 & 0.07 & 0.08 & 0.10 & 1.05 & 0.17 & 0.23 & 1.98 \\
\hline SD & & 0.26 & 0.06 & 0.19 & 0.25 & 0.08 & 0.17 & & 0.00 & 0.03 & 0.28 & 0.18 & 0.17 & 0.93 \\
\hline 3-Inner shelf & $9 / 98$ & 0.42 & 0.13 & ND & 0.39 & 0.13 & ND & ND & ND & NQ & 0.95 & NQ & NQ & 1.06 \\
\hline 3 & $7 / 99$ & 0.21 & 0.07 & 0.07 & 0.19 & 0.07 & 0.05 & 0.01 & 0.01 & 0.06 & 0.88 & 0.31 & 0.29 & 0.68 \\
\hline 3 & $4 / 00$ & 0.43 & 0.15 & ND & 0.25 & 0.16 & ND & ND & ND & NQ & 0.70 & NQ & NQ & 1.00 \\
\hline Mean & & 0.35 & 0.12 & 0.07 & 0.28 & 0.12 & 0.05 & 0.01 & 0.01 & 0.06 & 0.84 & 0.31 & 0.29 & 0.91 \\
\hline SD & & 0.10 & 0.03 & & 0.08 & 0.04 & & & & & 0.11 & & & 0.17 \\
\hline 4-Inner shelf & $4 / 99$ & 0.34 & 0.09 & 0.19 & 0.23 & 0.09 & 0.14 & 0.02 & 0.03 & 0.08 & 0.76 & 0.55 & 0.59 & 1.12 \\
\hline 4 & $7 / 99$ & 0.09 & 0.42 & ND & 0.17 & 0.09 & ND & ND & ND & NQ & 0.50 & NQ & NQ & 0.76 \\
\hline 4 & $4 / 00$ & 0.52 & 0.16 & 0.06 & 0.41 & 0.16 & 0.04 & 0.002 & 0.01 & 0.01 & 0.82 & 0.11 & 0.10 & 1.36 \\
\hline Mean & & 0.32 & 0.22 & 0.13 & 0.27 & 0.11 & 0.09 & 0.01 & 0.02 & 0.05 & 0.69 & 0.33 & 0.35 & 1.08 \\
\hline SD & & 0.18 & 0.14 & 0.07 & 0.10 & 0.03 & 0.05 & 0.01 & 0.01 & 0.04 & 0.14 & 0.22 & 0.25 & 0.25 \\
\hline
\end{tabular}

Chemical abbreviations: VAL, vanillin; VAD, acetovanillone; VAD, vanillic acid; SAL, syringaldehyde; SON, acetosyringone; SAD, syringic acid; FAD, ferulic acid; CAD, p-coumaric acid; C/V, cinnamyl/vanillyl ratio; S/V, syringyl/vanillyl ratio; (Ad/Al) $v$, vanillyl acid/aldehyde ratio; $(\mathrm{Ad} / \mathrm{Al})_{\mathrm{s}}$, syringyl acid/aldehyde ratio. $\Lambda_{8}=$ sum of vanillyl, syringyl and cinnamyl (FAD and CAD) phenols produced from the oxidation of 100 $\mathrm{mg}$ of organic carbon (Hedges and Mann, 1979). ND= not detected; $\mathrm{NQ}=$ not quantifiable; $\mathrm{SD}=$ standard deviation. 


\subsection{Bulk carbon characteristics in sediments}

There were no significant differences in bulk sediment parameters measured between Stations 1 and 2 (lower river) (Table 3). The range of percent organic carbon and total nitrogen in sediments at the lower river stations ranged from 0.5 to $1.9($ mean $=1.2 \pm 0.5)$ and 0.03 to 0.2 (mean $=0.1 \pm 0.05)$, respectively (Table $3)$. Although there was no significant $(p>0.05)$ relationship between river discharge and total carbon and nitrogen, the highest carbon and nitrogen values (in the river) occurred during the lowest flow period in November 1999 and February 2000 when the river discharge dropped below $<5000 \mathrm{~m}^{3} \mathrm{~s}^{-1}$. There was a significant $(p<0.05)$ positive relationship between percent fines $(<63 \mu \mathrm{m})$ and percent organic carbon in sediments of the lower river (Table 3). Molar carbon/nitrogen $(\mathrm{C} / \mathrm{N})$ ratios ranged from 9.4 to 18.7 $($ mean $=12.0 \pm 1.4)$ - the highest value occurred during peak river discharge in April 1999 (Table 3). Average percent organic carbon (mean $=0.9 \pm 0.08$ ) and $\mathrm{C} / \mathrm{N}$ molar ratios $(9.9 \pm 0.5)$ were significantly $(p< \pm 0.05)$ lower in shelf (Stations 3 and 4) sediments compared to lower river sediments (Table 3 ). A strong positive correlation was also found between percent organic carbon $(\% \mathrm{OC})$ and total nitrogen $(\% \mathrm{TN})$ at Stations $1\left(r^{2}=0.97\right)$ and $2\left(r^{2}=0.96\right)$ in river sediments (Fig. 3). Bulk $\delta^{13} \mathrm{C}$ values in lower river sediments ranged from $-24.65 \%$ to $-21.90 \%$ o $($ mean $=-23.20 \pm 1.09 \%$ ) (Table 3$)$. These values were generally more depleted than those found in shelf sediments $(-22.5 \%$ o to $-21.2 \%$ ) (Table 3$)$.

\subsection{Lignin-phenols in sediments}

The LOPs in sediments from the lower Mississippi River and Louisiana shelf are shown in Table 4. The $\Lambda_{8}$ values in the lower river ranged from 0.72 to 3.72 (mean $=1.78 \pm 0.23$ ) and while there was no significant relationship between $\Lambda_{8}$ and river discharge $(p>0.05)$, the highest value occurred during peak discharge in April 1999-which corresponded to the highest observed $\mathrm{C} / \mathrm{N}$ ratio of 18.7 and most depleted $\delta^{13} \mathrm{C}$ values (Tables 3 and 4 ). The $\Lambda_{8}$ values on the shelf ranged from 0.68 to 1.36 (mean= $1.0 \pm 0.25)$ and were significantly lower $(p<0.05)$ than the average value for lower river sediments (Table 4).

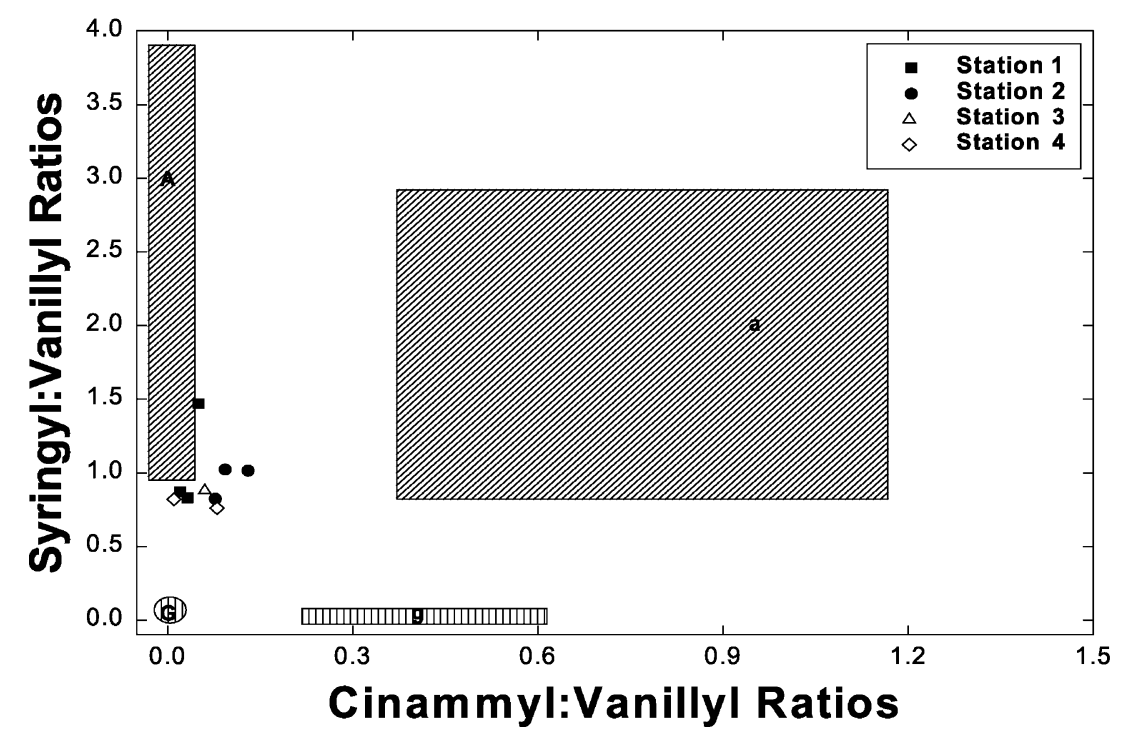

Fig. 4. Plot of syringyl/vanillyl (S/V) versus cinammyl/vanillyl $(\mathrm{C} / \mathrm{V})$ ratios in surface sediments $(0-2 \mathrm{~cm})$ collected from four stations in the lower Mississippi River (Stations 1 and 2) and Louisiana shelf (Stations 3 and 4) in 1998-2000. The boxed areas represent compositional ranges of major vascular plant tissues (Hedges and Mann, 1979; Goni and Hedges, 1992). Tissue abbreviations: A, woody angiosperms; a, nonwoody angiosperms; G, woody gymnosperms; g, non-woody gymnosperms. 
The compositional LOP ratios, syringyl/vanillyl (S/ $\mathrm{V})$ and cinnamyl/vanillyl $(\mathrm{C} / \mathrm{V})$ in the lower river ranged from 0.42 to 1.59 (mean $=0.99 \pm 0.09$ ) and those not quantifiable (NQ) to 0.15 (mean $=0.07 \pm$ 0.02 ), respectively (Table 4). The range of $\mathrm{S} / \mathrm{V}$ and $\mathrm{C} /$ $\mathrm{V}$ ratios on the shelf, 0.50 to 0.95 and NQ to 0.08 , respectively, and was similar to that found in the lower river (Table 4). Details on the sources of these LOPs have been discussed previously (Hedges and Mann, 1979). These ratios indicate that significant amounts of lignin in both the river and GOM were derived from angiosperm tissues (Fig. 4). Moreover, the low $\mathrm{C} / \mathrm{V}$ ratios indicate that this is likely a mixture of woody and non-woody sources and contains a woodier signature in the lower river than has been reported from recent studies in the general study area (Goni et al., 1997, 1998). Ratios of vanillic acid/vanillin (Ad/Al) and syringic acid/syringaldehyde $(\mathrm{Ad} / \mathrm{Al})_{\mathrm{s}}$, shown to be indicative of the diagenetic state of LOP (Hedges et al., 1988), ranged from NQ to 0.48 (mean $=0.20 \pm$ 0.07 ) and NQ to 0.43 (mean $=0.21 \pm 0.06$ ), respectively, in the lower river (Table 4). Similarly, $(\mathrm{Ad} / \mathrm{Al})_{\mathrm{v}}$ and $(\mathrm{Ad} / \mathrm{Al})_{\mathrm{s}}$ ratios on the inner shelf ranged from NQ to 0.55 and NQ to 0.59 , respectively.

\section{Discussion}

\subsection{Sources of lignin}

Although the highest inputs of terrestrially-derived organic matter occurred during high river discharge periods, there were no discernable trends in the sources of terrestrial organic matter in sediments. Terrestrial organic matter in the lower Mississippi River has a signature that appears to be predominantly com- posed of woody angiosperms throughout most of the year (Fig. 4, Table 4). There was a significant relationship between percent organic carbon and percent total nitrogen in sediments with a positive percent OC intercept at the zero percent TN (Fig. 3); this suggests that much of the nitrogen was likely in the form of organic nitrogen. The prominent salt wedge that occurred during some of the record low flow periods allowed for the intrusion of phytoplankton from the GOM (based on plant pigment biomarkers) that may have contributed to inputs of high nitrogen (predominantly diatom) detritus to the sediments (Bianchi et al., unpublished data).

\subsection{Transport and fate of lignin in the river}

Based on the low $\mathrm{C} / \mathrm{V}$ ratios, it appears that a significant fraction of terrestrially-derived materials in lower river and inner shelf sediments (within the riverine dispersal system) is derived from woody angiosperms. If we assume that the composition of terrestrial materials in sediments of the lower river is principally governed by the sedimentation of POC from upriver sources, these results are not consistent with recent work that suggests that much of the terrestrial POC upriver in the Mississippi River has a signature of non-woody angiosperms - believed to be derived from soils in northern grasslands (Goni et al., 1997, 1998; Onstad et al., 2000). There are two scenarios that could possibly explain these inconsistencies: (1) the contribution of woody angiosperm materials from the major drainage basins of the Missouri and Ohio Rivers has been underestimated in Mississippi River POC; (2) preferential sedimentation of woody organic matter (via hydrodynamic sorting) within the lower river and the primary riverine dispersal system on the shelf.

Recent work has shown that bulk POC derived from the dominant sources of grasslands in the Missouri River watershed does have a lignin signature that is typical of non-woody angiosperm sources; $\mathrm{C} / \mathrm{N}$ ratio of 9.6, $\Lambda_{6}$ values of 1 , relatively enriched $\delta^{13} \mathrm{C}$ of -19.4 , and $\mathrm{S} / \mathrm{V}$ and $\mathrm{C} / \mathrm{V}$ ratios of 0.94 and 0.25 , respectively (Onstad et al., 2000). Approximately $75 \%$ of the total sediment discharged from the lower Mississippi River is derived from the Missouri River. Nevertheless, the distinct woody angiosperm signal in the lower river and inner shelf sediments is unexpected, from a mass balance perspective, even with the aforementioned inputs of woody vascular plant materials to the Mississippi River (Table 4). Onstad et al. (2000) sampled the Mississippi River during a net depositional stagebased on the discharge values for the April and June 1986 time period. This likely resulted in the preferential loss of woody materials out of the water column. Moreover, Kendall et al. (2001) found that the average $\delta^{13} \mathrm{C}$ isotopic signature was -26 for fine-grained POC in the Mississippi River (St. Francisville, Louisiana), which is clearly more negative than the values reported by Onstad et al. (2000). So, the relative importance of woody angiosperm materials from the upper Mississippi basin (scenario 1) remains uncertain until more 
POC samples are collected across different flow regimes and with greater spatial resolution. However, hydrodynamic sorting (scenario 2) is likely affecting the distribution of terrestrially-derived particles in the river. Thus, a direct comparison between these POC values and our lower river sediments and inner shelf samples may be problematic due to selective loss of woody materials during this sampling period. This underscores the importance of differential particle settling as well as timing of discharge events when making predictions about the sources of particles in coastal margins.

Hydrodynamic sorting of sediment particles has been shown to be an important mechanism for distribution of terrestrially-derived organic matter along river-coastal margins (Prahl, 1985; Prahl et al., 1994; Jasper, 1995; Keil et al.,1998). The primary mechanism behind this is based on the idea that vascular plant detritus (primarily $\mathrm{C}_{3}$ plants) is retained in the inner bays and estuaries with coarse-grained mineral particles (Goni et al., 1997, 1998). As mentioned previously, the difference with the Mississippi River is that some of the woody angiosperm fraction, albeit small, is associated within the fine-grained POC that is coming from select tributaries in the upper Mississippi drainage basin (Onstad et al., 2000). Furthermore, the sedimentary carbon in the lower Mississippi River surface sediments sampled in this study has a woody angiosperm signature (Table 4). Onstad et al. (2000) also observed similar isotopic and lignin-phenol characteristics within the region of our sampling sites.

If we assume that bedload accounts for a minor fraction of the total POM transported by most large rivers (Richey et al., 1990; Leopold, 1994), and that the levee system along the entire lower Mississippi River precludes the input of large amounts of terrestrially-derived materials from local sources, the woody angiosperm signature in lower Mississippi River sediments is likely derived from the northern tributaries. This would imply that hydrodynamic sorting, typically associated with the relatively large particles of waterlogged woody material, is occurring in the lower river and the proximal portions of the riverine dispersal system on the shelf. The type of hydrodynamic sorting that we believe is occurring here is somewhat different than that described by Keil et al. (1998). In the Mississippi River, we propose that hydrodynamic sorting occurs primarily as a result of frequent resus- pension of sediments in the river bed caused by changes in river discharge, whereby the fine sediments are winnowed out in the water column and transported downstream, while the larger sediments/woody materials (with higher relative densities) selectively settle out in the lower river and inner shelf sediments.

\subsection{Hydrodynamic sorting of sedimentary organic carbon in the lower river and inner shelf}

Based on the following observations, we conclude that woody angiosperm POC, derived from upriver sources, is selectively removed within the lower Mississippi River and adjacent shelf: (1) the majority of fine-grained POC transported down river, predominantly from the Missouri River drainage basin, is primarily composed of a mixture of woody and nonwoody angiosperm materials (Onstad et al., 2000); (2) lower river and inner shelf sediments have relatively high concentrations of woody angiosperms (Table 4); (3) other shelf and slope sediments in the northern GOM, outside of the primary riverine dispersal system, are largely composed of non-woody sources (Goni et al., 1997,1998), with the exception of small patches of ${ }^{13} \mathrm{C}$ depleted sedimentary carbon due to remains of woody debris from sandy nearshore sediments (Sackett and Thompson, 1963; Hedges and Parker, 1976; Gearing et al., 1977). This hydrodynamic sorting of woody angiosperm materials in the lower river and inner shelf would add another stage of selective removal of terrestrially-derived particles before they are transported to other regions on shelf/slope - outside of the primary riverine dispersal system. Recent work by Goni et al. (1997, 1998), which did not include sampling transects within the primary dispersal system of the Mississippi River, showed essentially no woody plant signature on the shelf. Thus, it appears that riverine-derived woody tissues preferentially settle out of the water column, in the lower river and inner shelf, prior to the selective dispersal patterns of $\mathrm{C}_{3}$ versus $\mathrm{C}_{4}$ non-woody materials in other regions of the shelf and slope, as described by Goni et al. $(1997,1998)$.

\section{Summary}

Terrestrial organic matter in the lower Mississippi River has a signature that appears to be predominantly 
composed of woody angiosperms throughout most of the year. This suggests that the input of woody angiosperm sources to this region have been underestimated and is likely more important than previously thought (Goni et al. 1997, 1998). Hydrodynamic sorting, typically associated with the relatively large particles of water-logged woody material, is likely to occur in the river and the proximal portions of the riverine dispersal system on the shelf. This hydrodynamic sorting of woody angiosperm materials in the lower river and inner shelf would add another stage of selective removal of terrestrially-derived particles before they are transported to other regions on shelf/slope - outside of the primary riverine dispersal system. This work further demonstrates the importance of differential settlement of particles, sampling location within the dispersal system, and river discharge, when examining biogeochemical cycles in river-dominated margins.

\section{Acknowledgements}

We thank Nianhong Chen, Jeff Corbino, Dan Duncan, Martha Sutula, and Laura Wysocki for their assistance in the lab and field. This work was supported by a grant from the Department of Energy through the Center for Bioenvironmental Research at Tulane and Xavier Universities.

Associate editor: Dr. Maurizio Pettine.

\section{References}

Aller, R.C., 1998. Mobile deltaic and continental shelf muds as suboxic, fluidized bed reactors. Mar. Chem. 61, 143-155.

Berner, R.A., 1982. Burial of organic-carbon and pyrite sulfur in the modern ocean-its geochemical and environmental significance. Am. J. Sci. 282 (4), 451-473.

Bianchi, T.S., Lambert, C.D., Santschi, P.H., Guo, L., 1997. Sources and transport of land-derived particulate and dissolved organic matter in the Gulf of Mexico (Texas shelf/slope): the use of lignin-phenols and loliolides as biomarkers. Org. Geochem. $27,65-78$.

Demas, C., Curwick, P., 1988. Suspended sediment and associated chemical transport characteristics of the lower Mississippi River, Louisiana. Louisiana Dept. of Trans., Water Res. Tech. Rep. \#45, 43 p.

DeMaster, D.J., McKee, B.A., Nittrouer, C., Jiangchu, Q., Guodong, C., 1985. Rates of sediment accumulation and particle reworking based on radiochemical measurement from continen- tal shelf deposits in the East China Sea. Cont. Shelf Res. 4, $143-158$

Eadie, B.J., McKee, B.A., Lansing, M.B., Robbins, J.A., Metz, S., Trefry, J.H., 1994. Records of nutrient enhanced coastal productivity in sediments from the Louisiana continental shelf. Estuaries $17,754-765$.

Emmett, W., Leopold, L., Myrick, R., 1983. Some characteristics of fluvial processes in rivers. International Symposium on River Sedimentation Water Resources and Electric Power Press, Beijing.

Ertel, J.R., Hedges, J.I., 1985. Sources of sedimentary humic substances: vascular plant debris. Geochim. Cosmochim. Acta 49, 2097-2107.

Fry, B., Brand, W., Mersch, F.J., Tholke, K., Garrit, R., 1992. Automated analysis system for coupled ${ }^{13} \mathrm{C}$ and ${ }^{15} \mathrm{~N}$ measurements. Anal. Chem. 64, 288-291.

Gearing, P., Plucker, F.E., Parker, P.L., 1977. Organic carbon stable isotope ratios of continental sediments. Mar. Chem. 5, 251-266.

Goni, M.A., Hedges, J.I., 1992. Lignin dimers: structures, distribution and potential geochemical applications. Geochim. Cosmochim. Acta 56, 4025-4043.

Goni, M.A., Ruttenberg, K.C., Eglinton, T.I., 1997. Sources and contribution of terrigenous organic carbon to surface sediments in the Gulf of Mexico. Nature 389, 275-278.

Goni, M.A., Ruttenberg, K.C., Eglinton, T.I., 1998. A reassessment of the sources and importance of land-derived organic matter in surface sediments from the Gulf of Mexico. Geochim. Cosmochim. Acta 62, 3055-3075.

Hedges, J.I., Ertel, J.R., 1982. Characterization of lignin by gas capillary chromatography of cupric oxide oxidation products. Anal. Chem. 54, 174-178.

Hedges, J.I., Keil, R.G., 1995. Sedimentary organic matter preservation: an assessment and speculative synthesis. Mar. Chem. 49, $81-115$.

Hedges, J.I., Mann, D.C., 1979. The characterization of plant tissues by their lignin oxidation products. Geochim. Cosmochim. Acta 43, 1809-1818.

Hedges, J.I., Parker, P.L., 1976. Land-derived organic matter in the surface sediments from the Gulf of Mexico. Geochim. Cosmochim. Acta 40, 1019-1029.

Hedges, J.I., Stern, J., 1984. Carbon and nitrogen determinations of carbonate containing solids. Limnol. Oceanogr. 29, 657-663.

Hedges, J.I., Clark, W.A., Cowie, G.L., 1988. Organic matter sources to the water column and surficial sediments of a marine bay. Limnol. Oceanogr. 33, 1116-1136.

Jasper, J.P., 1995. Biomarkers and bulk organic sources record a history of sedimentary decoupling: results and a model. In: Grimalt, J.O., Dorronsoro, C. (Eds.), Organic Geochemistry: Developments and Applications to Energy, Climate, and Environment and Human History. 17th Intl. Meeting on Org. Geochem., 983-985.

Kendall, C., Silva, S., Kelly, V.J., 2001. Carbon and nitrogen isotopic compositions of particulate organic matter in four large river systems across the United States. Hydrol. Process.

Keil, R., Tsamakis, E., Giddings, J.C., Hedges, J.I., 1998. Biochemical distributions (amino acids, neutral sugars, and lignin phenols) among size-classes of modern marine sediments from 
the Washington coast. Geochim. Cosmochim. Acta 62, 13471364.

Leopold, L.B., 1994. A View of the River Harvard Univ. Press.

Malcolm, R., Durum, W., 1976. Organic carbon and nitrogen concentrations and annual organic carbon load of six selected rivers of the United StatesGeol Survey Water Supply Paper 1817-F, 21 pp.

McKee, B.A., Nittrouer, C.A., DeMaster, D.J., 1983. The concepts of sediment deposition and accumulation applied to the continental shelf near the mouth of the Yangtze River. Geology 11, $631-633$.

Meade, R., Parker, R., 1985. Sediment in rivers of the United States. National Water SummaryU.S. Geological Survey Water Supply Paper, vol. 2275, pp. 49-60.

Meade, R.H., Dunne, T., Richey, J.E., Santos, U.D., Salati, E., 1985. Storage and remobilization of suspended sediment in the Lower Amazon River of Brazil. Science 228 (4698), 488-490.

Meade, R., Yuzyk, T., Day, T., 1990. Wolman, H., Riggs, H. (Eds.), Movement and Storage of Sediment in Rivers of the United States and Canada, vol. $0-1,34-52$.

Milliman, J., 1991. Flux and fate of fluvial sediment and water in coastal seas. In: Mantoura, R.F.C., Martin, J., Wollast, R. (Eds.), Ocean Margin Processes in Global Change, Wiley, New York, pp. 69-90.

Nittrouer, C.A., Sternberg, R.W., Carpenter, R., Bennett, J.T., 1979. The use of $\mathrm{Pb}-210$ geochronology as a sedimentological tool: application to the Washington coastal shelf. Mar. Geol. 31, 297-316.

Onstad, G.D., Canfield, D.E., Quay, P.D., Hedges, J.I., 2000. Sour- ces of particulate organic matter in rivers from the continental USA: lignin phenol and stable carbon isotope compositions. Geochim. Cosmochim. Acta 64, 3539-3546.

Pereira, W.E., Hostettler, F.D., 1993. Nonpoint-source contamination of the Mississippi river and its tributaries by herbicides. Environ. Sci. Technol. 27 (8), 1542-1552.

Prahl, F.G., 1985. Chemical evidence of differential particle dispersal in the southern Washington coastal environment. Geochim. Cosmochim. Acta 49, 2533-2539.

Prahl, F.G., Ertel, J.R., Goni, M.A., Sparrow, M.A., Eversmeyer, B., 1994. Terrestrial organic carbon contributions to sediments on the Washington margin. Geochim. Cosmochim. Acta 58, 30353048.

Presley, B.J., Trefry, J.H., Shokes, R.F., 1980. Heavy metal inputs to Mississippi Delta sediments: a historical view. Water, Air, Soil Pollut. 13 (4), 481-494.

Richey, J.E., Hedges, J.I., Devol, A.H., Quay, P.D., Victoria, R., Martinelli, L., Forsberg, B.R., 1990. Biogeochemistry of carbon in the Amazon River. Limnol. Oceanogr. 35, 352-371.

Sackett, W.M., Thompson, R.R., 1963. Isotopic organic carbon composition of recent continental derived clastic sediments of the eastern Gulf coast, Gulf of Mexico. Bull. Am. Assoc. Pet. Geol. 47, 525-531.

Trefry, J.H., Metz, S., Nelson, T.A., Trocine, R.P., Eadie, B.J., 1994. Transport of particulate organic carbon by the Mississippi River and its fate in the Gulf of Mexico. Estuaries 17, 839-849.

Wells, F.C., 1980. Hydrology and water quality of the lower Mississippi River: Louisiana Office of Public Works Tech. Report \#21, 83 p. 